\title{
Limited prevalance of gaffkaemia (Aerococcus viridans var. homari) isolated from wild-caught European lobsters Homarus gammarus in England and Wales
}

\author{
P. D. Stebbing ${ }^{1, *}$, M. J. Pond ${ }^{1}$, E. Peeler ${ }^{1}$, H. J. Small ${ }^{2}$, S. J. Greenwood ${ }^{3}$, \\ D. Verner-Jeffreys ${ }^{1}$ \\ ${ }^{1}$ The Centre for Environment, Fisheries and Aquaculture Science (Cefas), Weymouth, Dorset DT4 8UB, UK \\ ${ }^{2}$ Virginia Institute of Marine Science, College of William \& Mary, PO Box 1346, Gloucester Point, Virginia 23062, USA \\ ${ }^{3}$ Department of Biomedical Sciences and AVC Lobster Science Centre, Atlantic Veterinary College, \\ University of Prince Edward Island, 550 University Ave, Charlottetown, Prince Edward Island C1A 4P3, Canada
}

\begin{abstract}
Gaffkaemia, caused by Aerococcus viridans var. homari, causes fatal infections in Homarus spp. (clawed lobsters). Despite its high economic significance to the lobster fisheries in the USA and northern Europe, data on its prevalence in captured and wild populations, particularly in Europe, is scarce. Following an outbreak of gaffkaemia in a European lobster holding facility in South Wales (UK), a base-line survey was conducted for gaffkaemia in wild populations of European lobster Homarus gammarus around the coast of England and Wales. In addition, isolates recovered from the original outbreak and the survey were typed using pulsed-field gel electrophoresis (PFGE) and compared with previously characterised isolates from the USA, UK and Canada. Locally caught $H$. gammarus were sampled at 30 sites from around the coast of England and Wales between March 2006 and October 2008. Results confirmed that the prevalence of gaffkaemia in populations of $H$. gammarus was low, with only 9 positive isolates recovered from 952 samples examined. PFGE analysis showed that the isolates from the outbreak investigation shared the same pulsotype as A. viridans var. homari isolates from the USA, Norway and Canada, as well as an isolate (NCIMB 1119) reportedly recovered from an outbreak of European lobsters in England in the 1960s. This confirms earlier studies that suggest virulent strains of $A$. viridans var. homari show very limited geographical or temporal genetic variation and were introduced into the UK with American lobsters $H$. americanus.
\end{abstract}

KEY WORDS: Lobster · Homarus gammarus $\cdot$ Homarus americanus $\cdot$ Bacteria $\cdot$ Aerococcus viridans Resale or republication not permitted without written consent of the publisher

\section{INTRODUCTION}

Gaffkaemia, a bacterial disease of clawed lobsters, is caused by a Gram-positive, tetrad-forming micrococcus, Aerococcus viridans var. homari (Snieszko \& Taylor 1947). It is recognised as one of the most damaging diseases known to the clawed lobster industry, causing fatal infections naturally in all Homarus spp. (Stewart et al. 1966 and reference therein). First recorded in the American lobster $H$. americanus $(\mathrm{H}$. Milne Edwards, 1837) in 1947 (Snieszko \& Taylor 1947), it is considered to be endemic to populations of H. americanus (Rabin 1965, Stewart et al. 1966, Stewart \& Rabin 1975) and to be of North American 
origin (Alderman 1996). Although primarily associated with mortalities of lobsters in holding facilities, it has also been found in wild populations of $H$. americanus in its natural range along the east coast of North America (Stewart et al. 1966, Vachon et al. 1981, Menard \& Myrand 1987, Lavallée et al. 2001).

Gaffkaemia has subsequently been found in Europe. Imports of Homarus americanus into the UK and other European countries were made economically practical with the development of trans-Atlantic commerce (Alderman 1996). Infected $H$. americanus arriving in the UK would be held in facilities containing European lobster H. gammarus (Linnaeus, 1758) resulting in a transfer of the disease. High mortalities caused by gaffkaemia have been reported in both species from holding facilities in a number of European countries: Norway (Roskam 1957, Egidius 1978), The Netherlands (Roskam 1957), Ireland (Gibson 1961, Alderman 1996) and the UK (Wood 1962, 1963, Ayres et al. 1973, Edwards et al. 1981). Reports have also been made of gaffkaemia found in wild lobster populations in Norway (Wiik et al. 1987) and the Orkney Islands (Nilsen et al. 2002 in Shields et al. 2006). Evidence has also been presented suggesting that gaffkaemia is present in UK waters. Wood (1962) reported no instances of gaffkaemia in England and Wales; however, in his 1963 ICES report Wood (1963) reported one incidence in a wild-caught European lobster from the south coast of England. Edwards et al. (1981) found no cases of gaffkaemia in wild stocks from around England and Wales. Despite there being only a single positive record from the wild in the UK, in some areas of England it is commonly believed that gaffkaemia is present in certain populations. Although occasional gaffkaemic lobsters are found in UK holding facilities, little is known on how the pathogen enters the facilities, especially where there has been no known contact with $H$. americanus. One potential source is from wild stocks of $H$. gammarus brought into the facilities.

In October 2006 heavy mortalities of European lobsters in a South Wales holding facility were reported to the Fish Health Inspectorate (FHI) at the Centre for Environment, Fisheries and Aquaculture Science (Cefas). An investigation by the FHI indicated that the facility had been suffering mortalities for approximately $1 \mathrm{wk}$, with $>75 \%$ of the European lobsters held either dead or moribund. All stock had been caught from local populations. No American lobsters had reportedly been held in the facility. The cause of the mortality was diagnosed as gaffkaemia, based on results from haemolymph-inoculated broth and agar (see below). This prompted an investigation into the source of the disease outbreak, and lobsters from the local population were found to be positive for gaffkaemia. Subsequently a baseline review of lobster population from around the coast of England and Wales was conducted.

The ability to identify specific strains of a bacterial pathogen is an essential tool for epidemiological investigations. To help determine the origins and relatedness of the Aerococcus viridans isolates recovered from wild Homarus gammarus and those held in storage, they were typed by using pulsedfield gel electrophoresis (PFGE) and compared with a range of isolates previously characterised by random amplified polymorphic DNA (RAPD) (Greenwood et al. 2005). PFGE is one of the most powerful molecular typing methods available and has been successfully applied to a range of different bacterial pathogens (Arbeit 1995), including some that affect fish (Vela et al. 2000, Nawawi et al. 2008, Wheeler et al. 2009); however, it had not previously been used for typing $A$. viridans.

This paper presents the results from the baseline survey (including the results from the initial disease investigation) for gaffkaemia in wild populations of Homarus gammarus from around the coast of England and Wales. A greater understanding of the status of gaffkaemia in wild lobster stocks would prove invaluable for holding facility owners by giving them a clearer idea of the disease status of source populations and allowing them to adopt appropriate management tools to reduce their potential exposure and impact of the disease. The results from the PFGE studies provide an indication of the source of the infections.

\section{MATERIALS AND METHODS}

Locally caught Homarus gammarus were sampled at 30 sites from around the coast of England and Wales between March 2006 and October 2008 (including the initial outbreak and sampling of source populations). The intention was to sample European lobsters as they were landed, directly from potting boats onto the dock. Due to logistical difficulties lobsters were also sampled from holding facilities from the same geographical region as they had been harvested, or from holding facilities where the lobsters had been held for a short period of time (less than $48 \mathrm{~h}$ ), and not held in contact with lobsters from other areas. From the 30 sites in the sampling programme (see Fig. 1), a total of 38 samples were taken, and 6 sites were sampled more than once. At each site approximately 30 lobsters were selected, with a pref- 


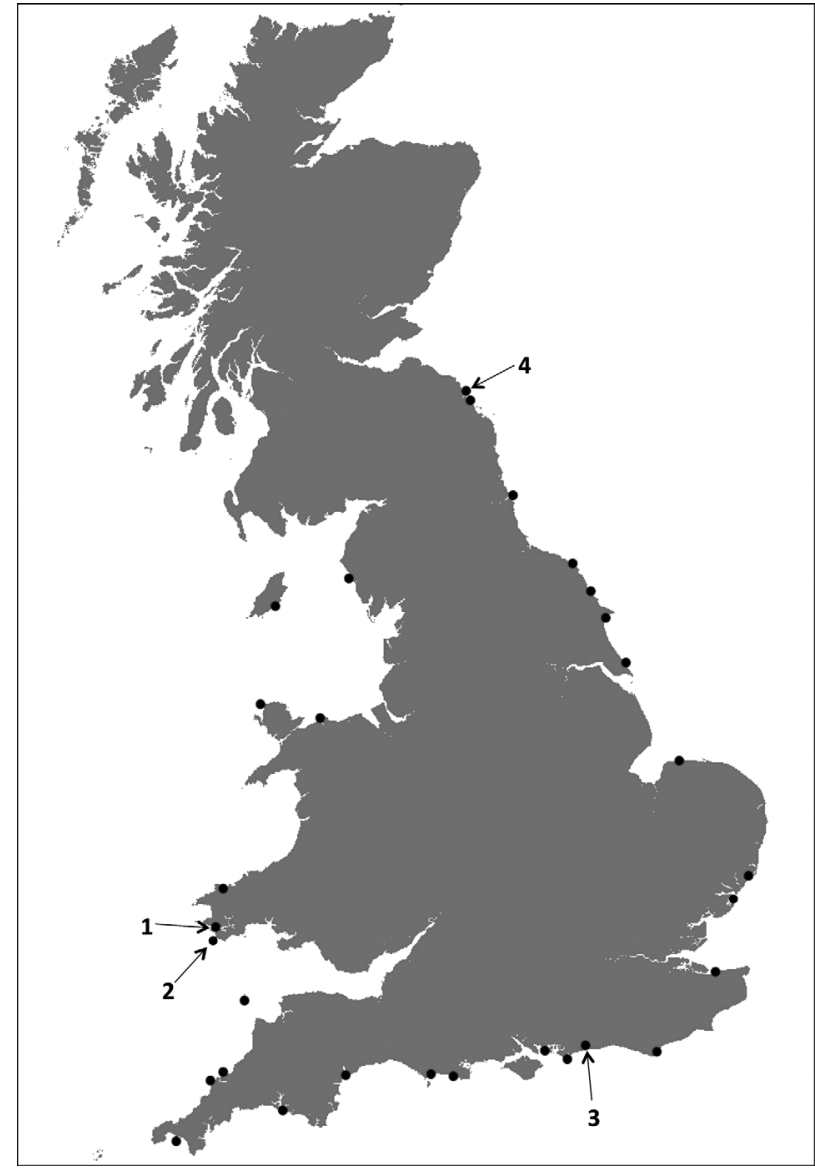

Fig. 1. The UK (excluding Northern Ireland) showing the distribution of samples taken as part of the study $(\bullet)$. Positive samples are numerically identified: Site 1 (South Wales holding facility); Site 2 (Pembroke coast, South Wales), which had supplied the holding facility (Site 1); Site 3, south coast of England, near Shoreham, West Sussex; Site 4, Northumberland, near Berwick

erence for individuals showing clinical signs of disease, missing limbs or damaged exoskeletons. This resulted in 952 lobsters sampled in total. Before sampling commenced the origin of the lobsters was confirmed, the carapace length and gender were recorded and notes on any general observations (e.g. missing appendages) were made. Progression of gaffkaemia is temperature dependent, with death occurring in $2 \mathrm{~d}$ at $20^{\circ} \mathrm{C}$ but $180 \mathrm{~d}$ at $3^{\circ} \mathrm{C}$ (Stewart 1975). Water temperatures rarely exceed $20^{\circ} \mathrm{C}$ in the UK, and lobsters in holding facilities are maintained at lower temperatures to avoid problems with gaffkaemia (highest temperature recorded during sampling was $16^{\circ} \mathrm{C}$ ). It was therefore considered unlikely for lobsters to have contracted gaffkaemia from within the holding facility and have died within the $48 \mathrm{~h}$ time period.

\section{Sampling and bacteriological culture}

Haemolymph was extracted from each lobster using a sterile disposable hypodermic syringe equipped with a 19 gauge needle. Point of extraction was either from the second joint of a walking leg or the ventral side of the cephalothorax. Before taking the haemolymph the surface area surrounding the point of extraction was sterilised with $100 \%$ alcohol. Lobsters were observed for a period of time after sampling to ensure that they were suffering no ill effects from the procedure.

Approximately $0.5 \mathrm{ml}$ of haemolymph was removed from each lobster and added to GAFF broth (a supplemented nutrient broth containing distilled water, $0.65 \%$ glucose [Merck], $0.45 \%$ yeast extract [Oxoid], $1.5 \%$ tryptone [Oxoid], $0.64 \%$ sodium chloride [Sigma], $0.25 \%$ phenylethanol alcohol [Fluke] and $0.0008 \%$ bromocresol purple [Sigma] as an indicator). These were subsequently transported on ice to the Cefas Weymouth Laboratory within $48 \mathrm{~h}$ and then incubated at $30 \pm 2^{\circ} \mathrm{C}$ for a further $14 \mathrm{~d}$.

Cultures were checked daily, and presumptive positive broths (those that changed in colour from purple to yellow) were subsampled by taking $10 \mu \mathrm{l}$ samples that were spread onto GAFF agar (Gaff broth with additional $1.2 \%$ Number 1 bacteriological agar [Oxoid]). The plates were incubated at $22 \pm 2^{\circ} \mathrm{C}$ for up to a further $14 \mathrm{~d}$. Suspect colonies (yellow on GAFF agar) were tested for Gram reaction (Buller 2004). Gram-positive isolates were further subcultured to purity on GAFF agar, and primary identification tests (cytochrome oxidase and catalase activity, motility and oxidation/fermentation reaction) were carried out (Buller 2004).

\section{S rRNA gene amplification and sequencing}

Isolates with a presumptive identification of Aerococcus sp. were confirmed by partial 16S rRNA gene sequencing. DNA sequences were obtained by amplifying a $529 \mathrm{bp}$ product corresponding to nucleotides 8 to 536 of the E. coli $16 \mathrm{~S}$ rRNA gene by PCR, using universal primers $16 \mathrm{~S}$ forward S-D-Bact008-a-S-20 (5'-AGA GTT TGA TCC TGG CTC AG$\left.3^{\prime}\right)$ and 16 S reverse S- ${ }^{*}$-Univ-0536-a-A-18 (5'-GWA TTA CCG CGG CKG CTG-3') (Suau et al. 1999). Template DNA for PCR was prepared by suspending 2 to 3 identical bacterial colonies in $100 \mu$ distilled water, heating $\left(94^{\circ} \mathrm{C}\right.$ for $\left.5 \mathrm{~min}\right)$, then immediately placing the lysate on ice. $50 \mu \mathrm{l}$ PCR reaction mixtures contained sterile molecular-grade water, $1 \times$ 
reaction buffer, $1.5 \mathrm{mM}$ magnesium chloride, $1.25 \mathrm{U}$ $(0.25 \mu \mathrm{l}) \mathrm{GoTaq}^{\circledR}$ polymerase (Promega), $0.25 \mathrm{mM}$ dNTPs and 50 pmol of each primer. A $2.5 \mu l$ aliquot of template was added to the reaction mixture, and samples were heated at $94^{\circ} \mathrm{C}$ for $5 \mathrm{~min}$ in a PTC-225 Peltier thermalcycler (MJ Research). Subsequently, 40 cycles of the following were carried out: denaturation at $95^{\circ} \mathrm{C}$ for $1 \mathrm{~min}$, annealing at $55^{\circ} \mathrm{C}$ for $1 \mathrm{~min}$ and elongation at $72^{\circ} \mathrm{C}$ for $1 \mathrm{~min}$, with a final elongation at $72^{\circ} \mathrm{C}$ for $10 \mathrm{~min}$. PCR products were purified by using Centricon ${ }^{\circledR}$ centrifugal filters (Millipore) or the Wizard ${ }^{\circledR}$ SV gel and PCR clean-up system (Promega), according to the manufacturers' instructions. In addition, the nearly full-length 16S rRNA gene sequences were also obtained for 2 of the isolates recovered from the holding facility in South Wales, and these were amplified using protocols previously described by Greenwood et al. (2005) with minor modifications. For this, approximately $10 \mathrm{ng}$ of genomic DNA was amplified in $20 \mu \mathrm{l}$ reactions containing $1 \times$ Green GoTaq Flexi Buffer (Promega), $1.5 \mathrm{mM} \mathrm{MgCl} 2,0.25 \mathrm{mM}$ of each dNTP, $1 \mu \mathrm{M}$ of each primer (BSF-8/20 and BSR-1541/20, see Greenwood et al. 2005) and 1 U Taq polymerase. Amplifications were performed with an initial denaturation of $94^{\circ} \mathrm{C}$ for $2.5 \mathrm{~min}$, followed by 35 cycles at $94^{\circ} \mathrm{C}$ for $1 \mathrm{~min}, 45^{\circ} \mathrm{C}$ for $1 \mathrm{~min}$ and $72^{\circ} \mathrm{C}$ for $1.5 \mathrm{~min}$, with a final elongation step at $72^{\circ} \mathrm{C}$ for $5 \mathrm{~min}$. After amplification, $10 \mu \mathrm{l}$ of each PCR product were analysed by agarose gel electrophoresis (1.5\% w/v), stained with ethidium bromide, and viewed under a UV light source. The PCR amplification products of approximately $1.5 \mathrm{~kb}$ were excised from agarose gels and purified using a QIA-quick gel extraction kit (Qiagen) and then cloned into the pGEM-T Easy Vector (Promega) following manufacturers procedures. Blue-white selection on Luria-Bertani (LB) agar plates containing ampicillin $\left(100 \mu \mathrm{g} \mathrm{ml} \mathrm{m}^{-1}\right)$, isopropyl-beta-D-thiogalactopyranoside (IPTG) $(0.1 \mathrm{mM})$ and X-gal (50 $\mu \mathrm{g} \mathrm{ml}^{-1}$ ) was used to identify insertpositive colonies. Three colonies from each plate were picked into $5 \mathrm{ml} \mathrm{LB}$ broth supplemented with ampicillin (100 $\left.\mu \mathrm{g} \mathrm{ml}^{-1}\right)$ and grown overnight at $37^{\circ} \mathrm{C}$. Plasmids were extracted using a QIAprep Spin MiniPrep Kit (Qiagen).

Purified PCR products and inserts were sequenced in both directions using the BigDye ${ }^{\circledR}$ Terminator sequencing kit (Applied Biosystems) according to the manufacturer's instructions. Sequencing was performed at the Cefas Weymouth Laboratory using an ABI 3700 DNA analyser. Inserts sequenced bidirectionally, as described above for the partial 16S rRNA gene PCR products.
Sequence data were assembled and initially analysed using the Sequencher program (Gene Codes). The bacterial species was identified by comparing the resulting consensus sequence with bacterial 16S rRNA sequences lodged with GenBank and EMBL using the basic local alignment search tool (BLAST) search program available at the UK HGMP Resource Centre, Hinxton (http://blast.ncbi.nlm.nih. gov/Blast.cgi) and using the Ribosome Database SeqMatch tool (available at http://rdp.cme.msu.edu/ seqmatch/seqmatch_intro.jsp). The partial 16S rRNA gene sequence data from isolates confirmed as Aerococcus sp. were also directly compared with the partial 16S rRNA gene sequences lodged in GenBank that were derived from the study by Greenwood et al. (2005).

\section{Pulsed-field gel electrophoresis}

Identified Aerococcus viridans isolates were compared using pulsed-field gel electrophoresis (PFGE) to other known isolates from Canada, England, Norway and the USA (Table 1), essentially according to the method described by Vela et al. (2000). In brief, pure cultures of $A$. viridans were grown overnight on tryptone soy agar (TSA; Oxoid) at $26^{\circ} \mathrm{C}$ and used to inoculate flasks of brain heart infusion broth (BHIB; Oxoid), which were incubated overnight in shaking culture at $37^{\circ} \mathrm{C}$. Cells were harvested by centrifugation $\left(2500 \times g\right.$ for $15 \mathrm{~min}$ at $\left.20^{\circ} \mathrm{C}\right)$ and resuspended in PIV buffer $(10 \mathrm{mM}$ Tris and $1 \mathrm{M}$ $\mathrm{NaCl}$, prepared in molecular grade deionised water [Sigma]). These were washed by an additional centrifugation step followed by resuspension in fresh PIV buffer. Agarose plugs were prepared and lysed in Sigrun's lysis buffer $(6 \mathrm{mM}$ Tris, $1 \mathrm{M} \mathrm{NaCl}$, $100 \mathrm{mM}$ EDTA, 0.5\% Brij 58, 0.2\% sodium deoxycholate, $0.5 \%$ sodium lauroyl sarcosine, $20 \mu \mathrm{g} \mathrm{ml} \mathrm{m}^{-1}$ RNase and $1 \mathrm{mg} \mathrm{ml}^{-1}$ lysozyme, prepared in molecular grade water), containing $0.1 \mathrm{mg} \mathrm{l}^{-1}$ proteinase $\mathrm{K}$ (Vela et al. 2003), for $4 \mathrm{~h}$ at $37^{\circ} \mathrm{C}$ with shaking at $200 \mathrm{rpm}$. Plugs were then washed overnight at $50^{\circ} \mathrm{C}$ in ES solution (0.5 M EDTA and $0.1 \%$ sodium lauroyl sarcosine (w/v) in molecular grade deionised water) containing $0.1 \mathrm{mg} \mathrm{ml}^{-1}$ proteinase K. Plugs were then washed 3 times in $15 \mathrm{ml}$ Tris-ethylenediaminetetraacetic acid buffer, each time for $1 \mathrm{~h}$ at $37^{\circ} \mathrm{C}$ with shaking at $140 \mathrm{rpm}$. A. viridans genomic DNA was digested in situ using the restriction enzymes, Sma1 (for $6 \mathrm{~h}$ at $25^{\circ} \mathrm{C}$, with shaking at $100 \mathrm{rpm}$ ) and, for some of the isolates, ApaI (for $12 \mathrm{~h}$ at $37^{\circ} \mathrm{C}$, with shaking at $\left.100 \mathrm{rpm}\right)$. A Salmonella 
Table 1. Aerococcus viridans var. homari. Isolates from Homarus gammarus or H. americanus used in the present study. Sma1 pulsotype assigned based on visual examination of pulsed-field gel electrophoretograms (1.3\% agarose) of Sma1 digests (Fig. 1)

\begin{tabular}{|c|c|c|c|c|c|}
\hline Isolate & Identification & Origin & $\begin{array}{c}\text { Isolation } \\
\text { year }\end{array}$ & Location & $\begin{array}{c}\text { Sma1 } \\
\text { pulsotype }\end{array}$ \\
\hline NCIMB $1119^{b}$ & A. viridans var. homari & H. gammarus & 1962 & Southampton, England, UK & Pt 1 \\
\hline ATCC $10400^{c}$ & A. viridans var. homari & H. americanus & 1947 & Maine, USA & Pt 1 \\
\hline Rabin & A. viridans var. homari & H. americanus & 1963 & Massachusetts, USA & Pt 1 \\
\hline Newfoundland & A. viridans var. homari & H. americanus & 1991 & Newfoundland, Canada & Pt 1 \\
\hline NVI $1032^{\mathrm{d}}$ & A. viridans var. homari & H. americanus & 1977 & NVI, Norway & Pt 1 \\
\hline NVI $1040^{\mathrm{e}}$ & A. viridans var. homari & H. americanus & 1977 & NVI, Norway & Pt 1 \\
\hline $37 \mathrm{R}$ & A. viridans-like coccus & H. americanus & 1964 & Prince Edward Island, Canada & Pt 4 \\
\hline $88 \mathrm{~B}$ & A. viridans-like coccus & H. americanus & 1962 & Nova Scotia, Canada & Pt 5 \\
\hline 06065 & A. viridans var. homari & H. gammarus & 2006 & S Pembrokeshire, Wales, UK (Site 1$)^{\mathrm{a}}$ & Pt 1 \\
\hline 06065 & A. viridans var. homari & H. gammarus & 2006 & S Pembrokeshire, Wales, UK (Site 1) ${ }^{\mathrm{a}}$ & Pt 1 \\
\hline 06066 & A. viridans var. homari & H. gammarus & 2006 & S Pembrokeshire, Wales, UK (Site 1) ${ }^{\mathrm{a}}$ & Pt 1 \\
\hline 07112 & A. viridans-like coccus & H. gammarus & 2007 & S Pembrokeshire coast, Wales, UK (Site 2) ${ }^{\mathrm{a}}$ & Pt 2 \\
\hline 07113 & A. viridans-like coccus & H. gammarus & 2007 & S Pembrokeshire coast, Wales, UK (Site 2) ${ }^{\mathrm{a}}$ & Pt 3 \\
\hline 09008 & A. viridans var. homari & H. gammarus & 2008 & S England, UK (Site 3) ${ }^{\mathrm{a}}$ & Pt 1 \\
\hline ATCC 700406 & A. viridans & Environment & & Not reported (USA) & Pt 6 \\
\hline \multicolumn{6}{|l|}{${ }^{\text {apresent study }}$} \\
\hline \multicolumn{6}{|c|}{ bIsolate deposited in National Collection of Industrial and Marine Bacteria (Wood 1963) } \\
\hline \multicolumn{6}{|c|}{ 'Original isolate of Snieszko \& Taylor (1947) } \\
\hline \multicolumn{6}{|c|}{${ }^{\mathrm{d}}$ National Veterinary Institute (NVI), Norway } \\
\hline
\end{tabular}

braenderup molecular standard was prepared by the same method and restricted in situ with $\mathrm{XbaI}$ (Hunter et al. 2005). ApaI and SmaI digested agarose blocks were loaded into a 1.3\% PFGEgrade agarose gel (Sigma) and electrophoresed by the contour-clamped electric field method in $0.5 \times$ Tris-borate-EDTA buffer (with $200 \mathrm{mM}$ thiourea) using a Bio-Rad CHEF DRII apparatus (Hercules). Molecular standards were included in every sixth well. Run conditions were $6.0 \mathrm{~V} \mathrm{~cm}^{-1}$ with switch times of 1 to $30 \mathrm{~s}$ at $14^{\circ} \mathrm{C}$ for $21 \mathrm{~h}$. Images were captured using a Gel Doc 2000 gel documentation system (Bio-Rad). The resultant profiles were compared manually.

\section{RESULTS}

Of the 952 samples that were examined, 11 isolates were presumptive positive for Aerococcus viridans based on colony morphology, growth on GAFF agar and results of primary tests. Of these presumptive positives, isolates from 9 samples were confirmed as A. viridans, based on the results of partial $16 \mathrm{~S}$ rRNA gene sequencing.

The 9 Aerococcus viridans isolates came from 4 separate sites: Site 1, 5 lobsters tested positive from the holding facility in South Wales that triggered the investigation in 2006; Site 2, 2 lobsters tested positive from the wild population from the Pembroke coast, South Wales, which had supplied the holding facility (Site 1); Site 3, one lobster tested positive from the south coast of England, near to Shoreham, West Sussex; Site 4, one lobster tested positive from the coast of Northumberland, near Berwick.

Using primers BSF-8/20 and BSR-1541/20 (Greenwood et al. 2005), $1419 \mathrm{bp}$ of Aerococcus viridans 16S rRNA sequence data were generated for the 2 Cefas A. viridans isolates from Site 1 . The $16 \mathrm{~S}$ rRNA sequences from both Cefas Isolates 7 and 8 showed a $100 \%$ similarity to each other and to sequences in GenBank derived from 7 other A. viridans var. homari isolates: NVI 1030, NVI 1032, ATCC 10400, ATCC 29838, Maine, Newfoundland and Rabin (GenBank accession numbers AY707775, AY707776, AY70777, AY707777, AY707778; Greenwood et al. 2005).

Using primers S-D-Bact-008-a-S-20 and S- *-Univ1492-b-A-21, 529 bp of partial 16S rRNA gene sequence data were also obtained from the isolates from Sites 2, 3 and 4. Isolates from Sites 3 and 4 also shared $100 \%$ sequence identity with the 7 Aerococcus viridans var. homari isolates previously sequenced by Greenwood et al. (2005). 
PFGE was successfully performed on isolates from Sites 1, 2 and 3, but the isolate from Site 4 lost viability before it could be tested. SmaI digested DNA resulted in profiles with approximately 12 to 16 major fragments (see Fig. 2). ApaI digested DNA resulted in profiles with approximately 10 to 15 major fragments. Three isolates from the first outbreak investigation at the holding facility (Site 1, Isolates 06066, 06067 and 06068), had the same restriction profiles (Pt 1, using either ApaI or SmaI) and were genetically indistinguishable from the Aerococcus viridans strain reportedly isolated from the UK in 1962 (NCIMB 1119), or a group of 5 isolates from infected Canadian and American Homarus americanus lobsters (ATCC 10400, Rabin Newfoundland, NVI 103 and NVI 1040a; Table 1, Fig. 2). The latter 6 isolates were previously characterised by Greenwood et al. (2005) as sharing the same RAPD profiles and able to cause gaffkaemia (were virulent at time of isolation). The 2 isolates from Site 2 (Isolates 07112 and 07113; Table 1, Fig. 2) that were collected from populations from the Pembrokeshire coast used to supply Site 1 had 2 different restriction profiles (Pt 2 and 3). With apparently 7 or more band differences between all 3 pulsotypes, this suggests that these isolates were genetically unrelated to each other (Tenover et al. 1995). The isolate from Site 3 (09008) also shared the same pulsotype (Pt 1) as the virulent isolates from North America and the holding facility (Site 1). Pulsotypes 4, 5 and 6 were unique to the USA and have not been reported from other locations.

Two of the 4 positive sites were retested (Sites 1 and 2) during the survey period. Site 1 initially tested positive on 24 October 2006 as it was suffering mortalities; subsequent testing on 13 November 2008 was negative. Site 2 initially tested negative on 26

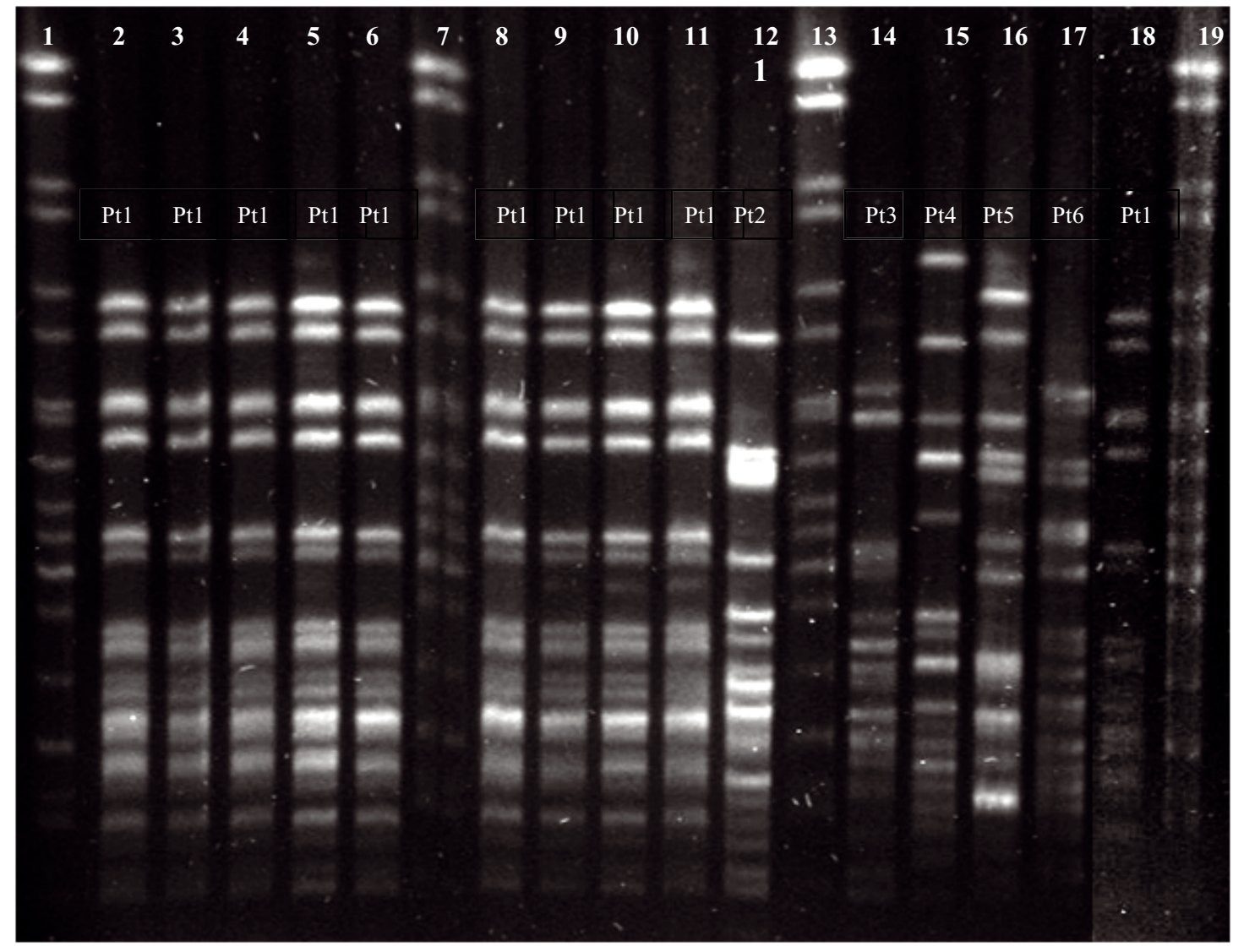

Fig. 2. Aerococcus viridans. Pulsed-field gel electrophoretogram (1\% agarose) of sma1 digests from isolates recovered from Homarus gammarus and H. americanus. Lane 2, 06065; Lane 3, 06066; Lane 4, 06067; Lane 5, Newfoundland; Lane 6, NCIMB 1119; Lane 8, NVI1032; Lane 9, Rabin; Lane 10, ATCC 10400; Lane 11, NVI 1040; Lane 12, 07112; Lane 14, 07113; Lane 15, 37R; Lane 16, 88b; Lane 17, ATCC 700406; Lane 18, 09008. Lanes 1, 7, 13 and 19, Salmonella braenderup molecular standard. Additional information on isolates is provided in Table 1. Pulsotypes (Pt) are marked on lanes 
April 2008; subsequent testing on the 4 June 2008 was positive.

The overall prevalence of Aerococcus viridans var. homari observed in lobsters within England and Wales during the study period was $0.95 \%$ (this excludes lobsters from the initial outbreak in the holding facility).

\section{DISCUSSION}

This paper confirms the presence of gaffkaemia in holding facilities and wild Homarus gammarus populations from England and Wales. The pathogen was isolated from 3 populations from different parts of the UK coastline (see Fig. 1), with an epidemiological association between 2 of the sites (Sites 1 and 2).

The first confirmed positive test for gaffkaemia in the UK was by Wood (1962). Aerococcus viridans var. homari strain NCIMB 1119, according to the accession information available from both the NCIMB and CETC (where it is also held), was reportedly isolated from diseased lobsters from Southampton in 1962 and deposited by Wood in 1963, referencing his report (Wood 1963). This strongly suggests that the outbreak reported by Wood (1963) was also caused by this virulent clade of $A$. viridans. The high genetic similarity of the isolates from the diseased lobsters in the holding facility (Site 1) with previously characterised pathogenic North American isolates (Pt 1; Fig. 2, Table 1) is suggestive of transfer of the bacterial pathogen to European lobsters in the UK from American lobsters at some point before 1962. It is not possible to determine whether this happened very recently (e.g. while the lobsters were in the holding facility), or instead, represented a transfer from wild lobsters that were carrying the disease. Gaffkaemia had been reported as early as 1952 from English holding facilities, so the potential presence of gaffkaemia in UK lobster stocks may date back as early as this. However, it should be noted that the survey reported by Edwards et al. (1981) found no signs of gaffkaemia in either wild or held lobsters tested as part of the survey. Therefore, there may have been a change in prevalence within populations or localisation in the distribution of the disease between these dates. Sampling 30 individuals gives a $95 \%$ likelihood of detecting at least one infected lobster if the prevalence is above $10 \%$ (assuming perfect sensitivity). It is therefore not possible to determine whether the pathogen is widespread at a very low prevalence, and hence went undetected in most samples, or whether its distribution is localised. In popu- lations where 1 in 30 animals tested positive (3.3\%) the true prevalence may be as low as $0.8 \%$ (lower $95 \% \mathrm{CI}$ ). The higher prevalence at the holding facility (Site 1) in Wales is probably explained by transmission within the facility. Assuming a minimum detectable prevalence of $0.8 \%$, a sample of 373 individuals at each sampling point would be required to have $95 \%$ confidence that the pathogen is absent.

Changes in gaffkaemia prevalence have been reported in several other studies, such as in Norway by Wiik et al. (1987) who reported $0.13 \%$ in 1981 and $0 \%$ in 1982 to 1984. Variations in prevalence have also been observed in Canada (Lavallée et al. 2001) with between 5.8 and $6.9 \%$ being recorded in waters off Prince Edward Island and between 0 and $22.6 \%$ in the Gulf of Maine (Vachon et al. 1981). Most of these differences can most plausibly be explained by variation that will inevitably arise from samples drawn from the same populations and do not provide strong evidence of a trend. However, the increase in prevalence from 0 to $22.6 \%$ in the Gulf of Maine suggests introduction of the agent, or conditions that promote efficient transmission between lobsters. There are, however, significant issues with the calculation of prevalence of disease within a population when tested lobsters have been caught using traps. Diseased lobsters are less likely to be active and therefore unlikely to enter traps, resulting in a potential underestimation of prevalence. The calculated prevalence of $0.95 \%$ for the test area used in this study should be taken as an estimate owing to the inherent bias of the sampling mechanisms used.

Greenwood et al. (2005) performed 16S rRNA gene sequence analysis and RAPD analysis on a geographically and temporally diverse collection of virulent and avirulent isolates of Aerococcus viridans. They determined that virulent isolates collected from diseased Homarus americanus from the USA, Norway and Canada shared the same RAPD profile. In this study, we have extended the analysis to also include typing isolates by PFGE with similar results (e.g. the pathogenic group of isolates). This further confirms the suggestion of Greenwood et al. (2005) that the pathogenic strains of $A$. viridans var. homari that infect North American lobsters represent a single genetically homogenous clade, regardless of their geographical, temporal or virulence differences.

Interestingly, the PFGE results show that the positive isolates taken from Sites 1 and 3 in this study also conform to the same shared Sma1 pulsotype (Pt 1) as the North American pathogenic subgroup. However, the positive isolates from Site 2 did not 
match those from Site 1 (which had supposedly been supplied from Site 2), but also did not match with any other isolate tested. As there were no apparent mortalities relating to the isolation of this strain, more work is required to determine if it is pathogenic and to investigate its origins. These results suggest that there may be 2 strains of gaffkaemia present in wild populations off the South Welsh coast, one of which resulted in the infection at Site 1 and the additional strain found during the testing of the wild stock (Site 2).

This study has provided further evidence that the same pulsotype of Aerococcus viridans responsible for disease outbreaks in US lobsters is often the same cause of gaffkaemia in captured lobsters in UK waters. Despite this there have been no recorded mortality events in wild lobster populations associated with the presence of the disease, although the difficulty in detecting disease-related mortalities in benthic hosts in the marine environment should be noted. However, the only mortalities observed during this study, as a result of gaffkaemia, were in the holding facility at Site 1. Infected lobsters may be able survive within a wild population, only succumbing to the infection when stressed (e.g. capture and captivity). This highlights the need for the development and adoption of good practices by holding facility operators to maintain biosecure premises and develop measures to reduce stress on the lobsters and the introduction and spread of disease within their facilities. However, to further assist holding facility operators and fishers there is still a need for further investigations to determine the true prevalence and distribution of gaffkaemia in UK waters.

\section{LITERATURE CITED}

Alderman DJ (1996) Geographical spread of bacterial and fungal diseases of crustaceans. Rev Sci Tech Off Int Epizoot 15:603-632

Arbeit RD (1995). Laboratory procedures for the epidemiological analysis of microorganisms. In: Murray PR, Baron EJO, Pfaller MA, Tenover FC, Yolken RH (eds) Manual of clinical microbiology, 6th edn. American Society for Microbiology, Washington, DC, p 190-208

Ayres PA, Halls S, Edwards E (1973) Incidence of Gaffkya homari in natural lobster stocks- preliminary results of a survey of the English and Welsh fisheries. ICES Shellfish Comm No. 20. ICES, Copenhagen

Buller NB (2004) Bacteria from fish and other aquatic animals: a practical identification manual. CABI Publishing, Wallingford

Edwards E, Ayres PA, Cullum ML (1981) The incidence of the disease gaffkaemia in native (Homarus gammarus) and imported lobsters (Homarus americanus) in England and Wales. ICES Shellfish Comm No. 12. ICES, Copenhagen

Egidius E (1978) Lobster import: 2 outbreaks of gaffkemia in Norway. ICES Shellfish Comm No. 17. ICES, Copenhagen

Gibson FA (1961) Gaffkaemia in stored lobsters. ICES Shellfish Comm No. 58. ICES, Copenhagen

Greenwood SJ, Keith IR, Després BM, Cawthorn RJ (2005) Genetic characterization of the lobster pathogen Aerococcus viridans var. homari by rRNA gene sequence and RAPD. Dis Aquat Org 63:237-246

Hunter SB, Vauterin P, Lambert-Fair MA, Van Duyne MS, Kubota K, Graves L, Wrigley D, Barrett T, Ribot E (2005) Establishment of a universal size standard strain for use with the PulseNet standardized pulsed-field gel electrophoresis protocols: converting the national databases to the new size standard. J Clin Microbiol 43:1045-1050

Lavallée J, Hammell KL, Spangler ES, Cawthorn RJ (2001) Estimated prevalence of Aerococcus viridans and Anophryoides haemophila in American lobsters Homarus americanus freshly captured in the waters of Prince Edward Island, Canada. Dis Aquat Org 46:231-236

Menard J, Myrand B (1987) L'incidence d'Aerococcus viridans var. homari dans le stock naturel de homards (Homarus americanus) des îles de la Madeleine (Québec), suite à une épidémie de gaffkémie dans un élevage in situ. Can J Fish Aquat Sci 44:368-372

Nawawi RA, Baiano J, Barnes AC (2008) Genetic variability amongst Streptococcus iniae isolates from Australia. J Fish Dis 31:305-309

Rabin H (1965) Studies on gaffkemia, a bacterial disease of the American lobsters, Homarus americanus (MilneEdwards). J Invertebr Pathol 7:391-397

Roskam RT (1957). Gaffkaemia, a contagious disease, in Homarus vulgaris. ICES Shellfish Comm No. 1 (mimeo). ICES, Copenhagen

Shields JD, Stephens FJ, Jones JB (2006) Pathogens, parasites and other symbionts. In: Phillips BF (ed) Lobsters: biology, management, aquaculture and fisheries. Blackwell Scientific, Oxford, p 146-204

Snieszko SF, Taylor CC (1947) A bacterial disease of the lobster (Homarus americanus). Science 105:500

Stewart JE (1975) Gaffkaemia, a fatal infection of lobsters (genus Homarus) caused by Aerococcus viridans (var.) homari: a review. Mar Fish Rev 37:20-24

Stewart JE, Rabin H (1975). Gaffkemia, a bacterial disease of lobsters (Genus Homarus). In: Snieszko SF (ed) A symposium on diseases of fishes and shellfishes. Am Fish Soc Spec Publ No. 5. Am Fish Soc, Washington, DC, p 431-439

Stewart JE, Cornick JW, Spears DI (1966) Incidence of Gaffkya homari in natural lobster (Homarus americanus) populations of the Atlantic Region of Canada. J Fish Res Board Can 23:1325-1330

Suau A, Bonnet R, Sutren M, Godon JJ, Gibson GR, Collins MD, Doré J (1999) Direct analysis of genes encoding 16S rRNA from complex communities reveals many novel molecular species within the human gut. Appl Environ Microbiol 65:4799-4807

Tenover FC, Arbeit RD, Goering RV, Mickelsen PA, Murray BE, Persing DH, Swaminathan B (1995) Guest commentary: interpreting chromosomal DNA restriction patterns produced by pulsed-field gel electrophoresis: criteria for bacterial strain typing. J Clin Microbiol 33: 2233-2239 
Vachon NS, Bayer RC, Rittenburg JH (1981) Incidence of $A$. viridans in American lobster populations from the Gulf of Maine. Prog Fish-Cult 43:49

Vela AI, Vasquez J, Gibello A, Blanco MM and others (2000) Phenotypic and genetic characterization of Lactococcus garvieae isolated in Spain from lactococcosis outbreaks and comparison with isolates of other countries and sources. J Clin Microbiol 38:3791-3795

Vela AI, Goyache J, Tarradas C, Luque I and others (2003) Analysis of genetic diversity of Streptococcus suis clinical isolates from pigs in Spain by pulsed-field gel electrophoresis. J Clin Microbiol 41:2498-2502

Wheeler RW, Davies RL, Dalsgaard I, Garcia J, Welch TJ,

Editorial responsibility: Mark Butler,

Norfolk, Virginia, USA
Wagley S, Bateman KS, Verner-Jeffreys DW (2009) Biotype 2 isolates from mainland Europe and the UK likely represent different clonal groups. Dis Aquat Org 84: 25-33

Wiik R, Egidius E, Goksøyr J (1987) Screening of Norwegian lobsters Homarus gammarus for the lobster pathogen Aerococcus viridans. Dis Aquat Org 3:97-100

Wood PC (1962) A preliminary note on gaffkaemia investigations in England. ICES Shellfish Comm No. 31. ICES, Copenhagen

Wood PC (1963) Blood disease of lobsters (gaffkaemia) results of investigations made 1962-1963. ICES Shellfish Comm No. 25. ICES, Copenhagen

Submitted: November 30, 2011; Accepted: May 23, 2012 Proofs received from author(s): August 14, 2012 